\title{
PERANCANGAN SISTEM PENCUCI TANGAN OTOMATIS TANPA SENTUH UNTUK MENCEGAH PENULARAN VIRUS COVID-19
}

\author{
Suraidi ${ }^{1}$, \\ Program Studi Teknik Elektro Universitas Tarumanagara \\ Email: suraidi@ft.untar.ac.id \\ Meirista Wulandari ${ }^{1}$ \\ Program Studi Teknik Elektro Universitas Tarumanagara \\ Email:meiristaw@ft.untar.ac.id
}

\begin{abstract}
S : This study discusses an automatic hand washing system with water and liquid soap that comes out automatically. The results of this study are used as material for electronics training activities at high school level in the form of community service activities. This system can be applied to a place to wash hands in schools, colleges or malls. Water sources can be collected or directly using a water pipe, while liquid soap uses a bottle holder or the like. The water and liquid soap control system has a separate or separate circuit. The system for controlling water consists of an infrared sensor module which is applied as a proximity sensor, a relay module and a solenoid valve to open or close the water tap. The use of a solenoid valve when the water source uses a direct tap and the use of a water pump for the water source uses a reservoir. The system for controlling liquid soap consists of a proximity sensor module, a switching transistor circuit, and a mini DC submersible pump. All modules are tested to determine the characteristics of each module, so that you know the type of relay module and switching transistors to be used. The type of relay used is the active low type and the switching transistor type used is PNP. There were two systems that were tested, and they worked properly according to the original design, so it could be said that the whole system was working well. System testing can be seen at the following link https://www.youtube.com/watch?v=gi5XiWMZuNU\&t=51s
\end{abstract}

Keyword: automatic hand washing system, water controller, liquid soap controller

ABSTRAK: Penelitian ini membahas tentang sistem mencuci tangan otomatis dengan air dan sabun cair yang keluar secara otomatis. Hasil penelitian ini sebagai materi untuk kegiatan pelatihan elektronika di sekolah tingkat SMA dalam bentuk kegiatan pengabdian kepada masyarakat. Sistem ini bisa diterapkan untuk tempat mencuci tangan di sekolah, kampus atau mall. Sumber air bisa dengan ditampung atau langsung menggunakan pipa air, sedangkan sabun cair menggunakan tempat botol atau sejenisnya. Sistem pengendali air dan sabun cair mempunyai rangkaian yang terpisah atau tersendiri. Sistem untuk mengendalikan air terdiri dari modul sensor infra merah yang diaplikasikan sebagai sensor proximity, modul relay dan solenoid valve untuk membuka atau menutup keran air. Penggunaan solenoid valve bila sumber air menggunakan keran langsung dan penggunaan pompa air untuk sumber air menggunakan penampungan. Sistem untuk mengendalikan sabun cair terdiri dari modul sensor proximity, rangkaian transistor switching, dan pompa mini DC celup. Semua modul diuji untuk mengetahui karakteristik tiap modul, sehingga mengetahui jenis modul relay dan transistor switching yang akan digunakan. Jenis relay yang digunakan yaitu jenis aktif low dan jenis transistor switching yang digunakan yaitu PNP. Ada dua sistem yang diuji, dan bekerja dengan baik sesuai dengan rancangan semula, sehingga bisa dikatakan sistem keseluruhan bekerja dengan baik. Pengujian sistem dapat dilihat pada link berikut https://www.youtube.com/watch? $\mathrm{v}=$ gi5XiWMZuNU\&t=51s

Kata Kunci: sistem cuci tangan otomatis, pengendali air, pengendali sabun cair

\section{PENDAHULUAN}

$\mathrm{P}$ enelitian ini untuk menghasilkan sebuah sistem pencuci tangan otomatis yang mana sistem ini untuk digunakan pada saat kondisi pandemik Covid-19 sekarang ini. Merebaknya virus Covid-19 di Indonesia telah berlangsung lebih dari satu tahun semenjak kasus pertama diumumkan oleh Presiden Joko Widodo pada 2 Maret 2020. Kasus pasien positif terinfeksi masih terus meningkat, penerapan protokol kesehatan tidak boleh kendor dan diabaikan. Mencuci tangan dengan air mengalir adalah bagian krusial, selain menggunakan masker dan menjaga jarak minimal 1,5 meter. Kendati demikian, fasilitas cuci tangan dengan air mengalir secara otomatis belum selalu tersedia. Penelitian ini merupakan salah satu cara untuk mendukung pemerintah dalam mencegah penyebaran virus Covid19. Hasil rancangan sistem ini juga sebagai materi untuk pelatihan pengabdian kepada masyarakat di sekolah SMA. Sistem serupa yang sudah ada saat ini, seperti penggunaan pedal injak untuk mengontrol air, tetapi penggunaan sabun cair masih menggunakan botol yang ditekan, ada pula yang sudah otomatis menggunakan sensor dan mikrokontroler.

Sistem yang dirancang merupakan sistem yang sangat sederhana, yaitu sistem pengendali air atau untuk membuka dan menutup keran air secara otomatis, dan sistem pengendali sabun cair atau

\footnotetext{
${ }^{1}$ Program Studi Teknik Elektro Universitas Tarumanagara
} 
untuk menuangkan sabun cair secara otomatis sesuai kebutuhan. Sistem ini dibuat sangat sederhana yaitu tidak menggunakan mikrokontroler, sehingga dapat memberikan manfaat buat masyarakat banyak jika ingin membuatnya.

Penelitian ini dimaksudkan untuk memperjelas sistem yang digunakan, serta jenis rangkaian atau modul yang digunakan, dan dapat membagikan ilmu cara membuat sistem ini secara mudah dengan membaca hasil penelitian ini. Penelitian ini dilakukan untuk meningkatkan kualitas mahasiswa program studi Teknik Elektro dibidang praktek, dan juga orang awam yang memerlukannya.

\section{SISTEM}

Sistem mencuci tangan otomatis dapat digunakan di sekolah, kampus atau mall. Sistem ini dilengkapi dengan sensor proximity, modul relay, rangkaian transistor switching, dan beban berupa solenoid valve dan juga pompa mini DC. Sistem mencuci tangan otomatis tersebut dirancang untuk mencuci tangan tanpa menyentuh keran air dan tempat sabun cair. Sistem ini akan mendeteksi adanya tangan dengan jarak hanya beberapa centimeter dari keran atau tempat sabun cair. Sistem ini mempunyai dua bagian yang terpisah, yaitu bagian pengendali air dan bagian pengendali sabun cair. Masing-masing diagram blok diperlihatkan pada Gambar 1 dan Gambar 2.

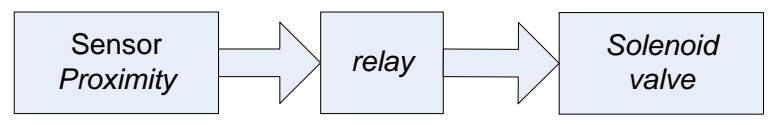

- Gambar 1. Diagram Blok Sistem Pengendali Air

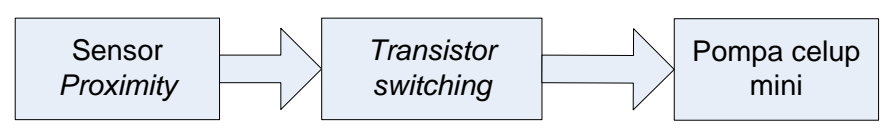

— Gambar 2. Diagram Blok Sistem Pengendali Sabun Cair

Komponen-komponen penyusun dari sistem ini adalah:

1. Sensor proximity sebagai pendeteksi tangan.

2. Modul relay untuk mengaktifkan solenoid valve atau pompa air.

3. Rangkaian transistor switching untuk mengaktifkan pompa celup mini dengan daya DC.

4. Power bank untuk sumber tegangan sistem

5. Kabel Jumper female-to female

6. Pin header male

7. Konektor USB

8. Kabel power

Cara kerja sistem pada Gambar 1 dan Gambar 2 mempunyai alur yang sama, yaitu sensor proximity untuk mendeteksi tangan, bila ada tangan maka data keluaran bernilai "low". Data "low" ini untuk mengaktifkan transistor switching atau modul relay, dimana transistor switching bila aktif akan menyalakan pompa celup dan modul relay aktif akan mengaktifkan solenoid valve.

\section{Sensor proximity}

Sensor ini merupakan aplikasi infra merah untuk mendeteksi halangan sebuah benda. Halangan atau objek yang terdeteksi hanya sebatas jarak beberapa centimeter saja $(2-30 \mathrm{~cm})$. Modul sensor proximity ini dapat dilihat pada Gambar 3 berikut: 


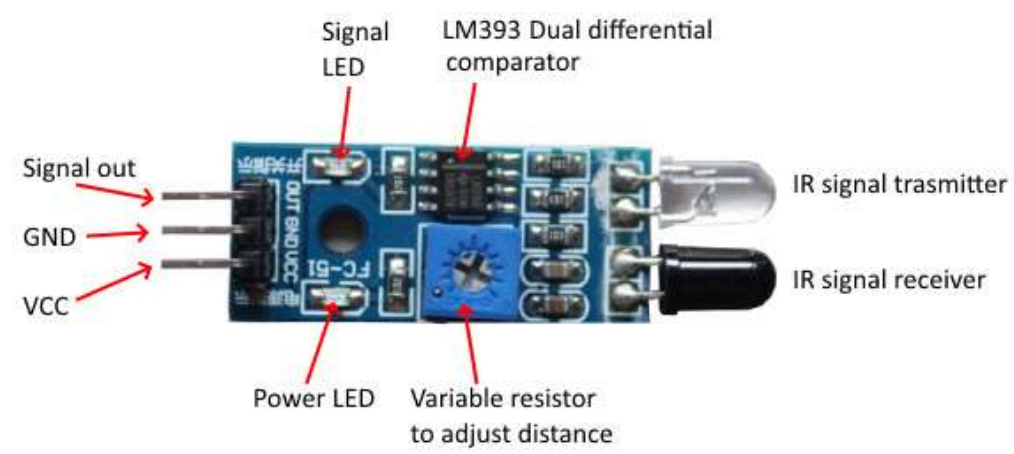

Gambar 3. Modul Sensor Proximity

Bagian - bagian dari modul tersebut :

- IC LM393 Comparator berfungsi untuk menghasilkan data output yang mulus dalam arti bit 0 dan bit 1 mempunyai nilai yang masuk dalam standard.

- Lampu IR transmitter sebagai pemancar sinar infra merah

- Diode IR receiver sebagai photodiode penerima sinar infra merah

- Power LED sebagai indikator bahwa modul ini mendapatkan tegangan supply

- Signal LED sebagai indikator untuk penanda jika ada objek yang terdeteksi

- Variable resistor sebagai setting sensitivitas dari jarak deteksi $(2-30 \mathrm{~cm})$

- Ada 3 pin, pin $\mathrm{VCC}=$ tegangan supply 5 volt (tegangan + dari supply), pin GND = tegangan (-) dari supply atau ground nya, dan pin Signal Out = sinyal data out dari modul ini.

Cara kerja sensor infra merah proximity mempunyai prinsip memantulkan sinar infra merah dan hasil pantulan sinar merah itu yang diterima dan diproses. Cara kerja ini dapat digambarkan seperti pada Gambar 4.

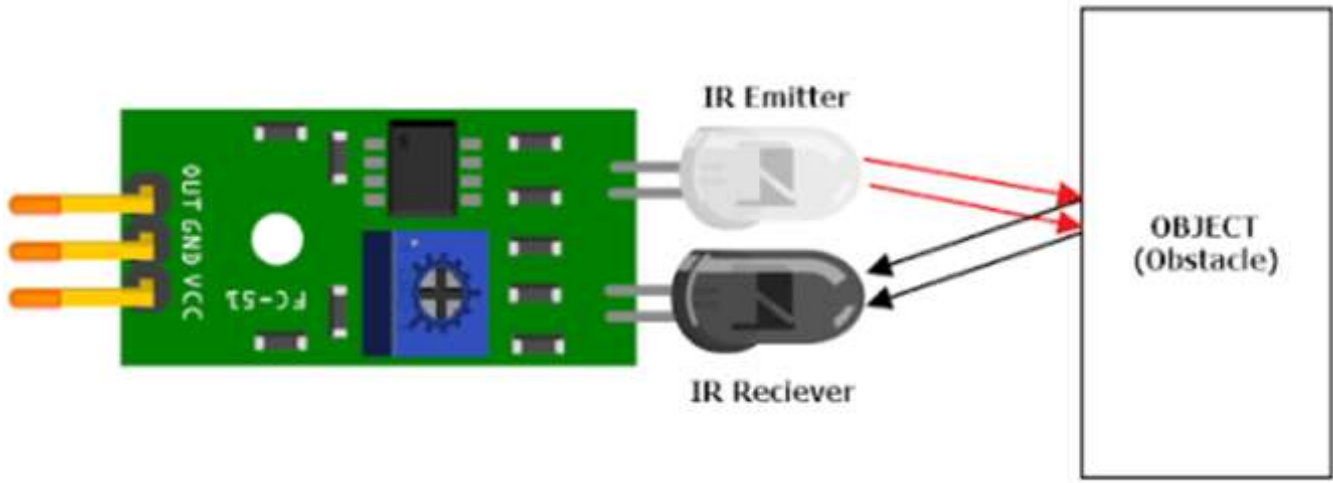

Gambar 4. Cara Kerja Sinar Infra Merah pada Modul

\section{Modul relay}

Modul ini untuk rangkaian penghubung antara tegangan DC sebagai pengendali dan tegangan AC sebagai tegangan beban, diaktifkan secara tegangan DC untuk menyalakan peralatan tegangan AC. Gambar modul dapat dilihat pada Gambar 5.

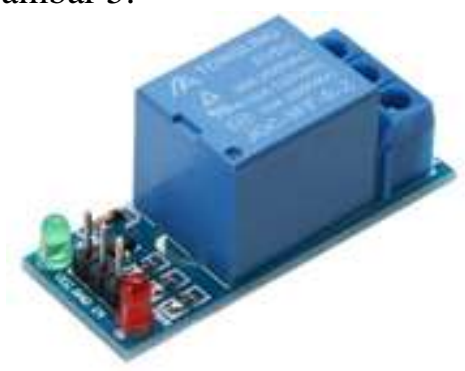

Gambar 5. Modul Relay 
Skematik dari modul relay ini dapat dilihat pada Gambar 6.

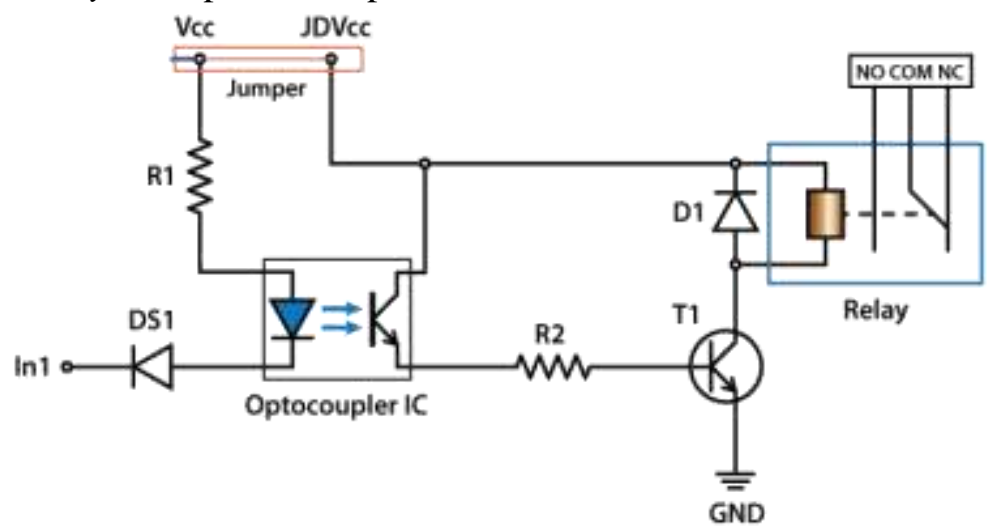

- Gambar 6. Skematik Modul Relay

Skematik tersebut memperlihatkan bahwa modul ini aktif "low", atau dengan kata lain, relay ini di "on" kan dengan memberikan data "low". Relay ini sama dengan cara kerja switch "on" atau "off", On artinya switch tertutup, sedangkan Off artinya switch terbuka. Cara kerja tersebut yang akan dirancang oleh karena itu pin yang digunakan yaitu pin COM dan NO saja.

\section{Solenoid valve}

Solenoid valve ini merupakan keran air dengan on/off airnya dengan menggunakan tegangan, jika tegangan diberikan Solenoid valve maka keran akan terbuka dan mengalirkan air, jika tegangan tidak diberikan maka keran akan tertutup dan air tidak keluar. Solenoid valve dapat dilihat pada Gambar 7.

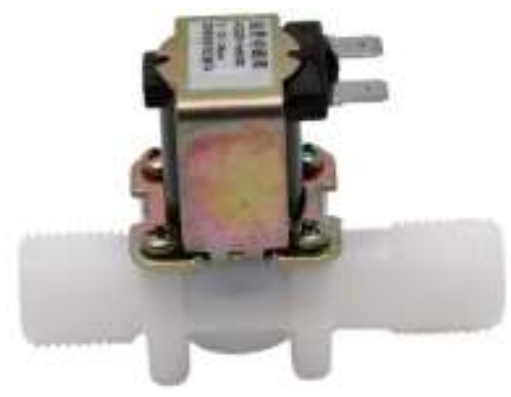

Gambar 7. Solenoid Valve

Tegangan supply untuk solenoid valve ini yaitu 220 Vac. Penggunaan solenoid valve dipilih dengan tegangan 220 Vac karena pertimbangan penggunaan tegangan supply yang langsung menggunakan tegangan PLN. Solenoid ini digunakan untuk sumber air dari keran / air dengan tekanan atau pipa air yang sudah ada, bila menggunakan tempat penampungan air maka solenoid ini diganti dengan pompa air untuk aquarium celup dengan daya AC.

\section{Transistor switching}

Rangkaian transistor switching mempunyai fungsi sebagai switch on/off berdasarkan data yang diberikan. Data yang dibutuhkan untuk mengaktifkan modul ini dirancang data "low", atau disebut dengan aktif "low". Dipilihnya jenis aktif "low" dikarenakan penggunaan modul sensor proximity yang data keluarannya bernilai "low" pada saat objek terdeteksi. Rangkaian transistor switching menggunakan tipe PNP dan diperlihatkan pada Gambar 8. Beban yang digunakan adalah pompa celup mini DC. 


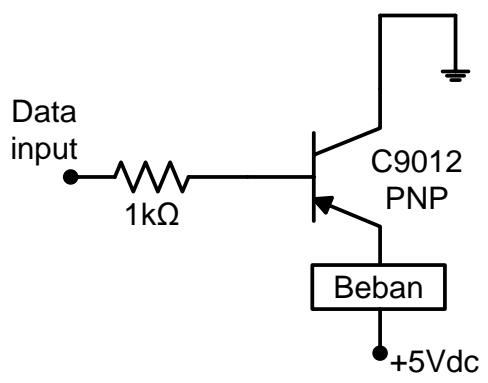

Gambar 8. Modul Transistor Switching

\section{Pompa celup mini DC}

Pompa celup mini DC ini digunakan untuk mengalirkan bahan cair dari sebuah wadah keluar, digunakan tipe celup ini untuk mengalirkan sabun cair, dan dapat dimasukkan ke dalam tempat sabun cairnya. Pompa ini membutuhkan tegangan DC untuk aktif, besar tegangan nya $5 \mathrm{Vdc}$, sehingga cocok digunakan untuk rangkaian ini. Gambar 9. menunjukkan bentuk pompa celup mini ini.

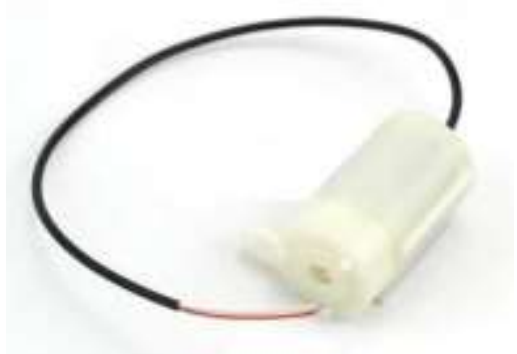

Gambar 9. Pompa Mini DC

\section{Kabel jumper konektor female to female}

Konektor ini digunakan untuk menghubungkan antar pin, dengan ujung kabel female dan ujung lain nya jenis female. Gambar konektor ini dapat dilihat pada Gambar 10.

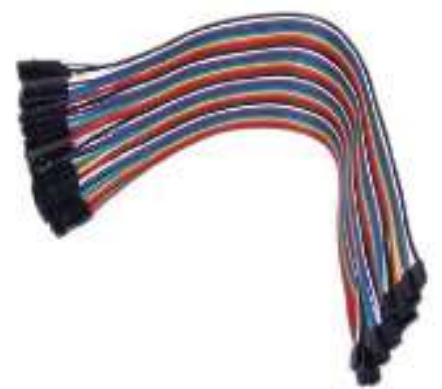

Gambar 10. Konektor Female to Female

\section{METODE PENELITIAN}

Metode yang dilakukan dengan membuat langsung aplikasi rangkaian secara nyata. Sistem ini bisa langsung diterapkan pada kebutuhan di lapangan. Prosedur penelitian dengan diuji terlebih dahulu setiap modul, dilakukan pengujian tiap modul untuk memastikan kondisi data yang sama untuk setiap bagian sehingga dapat berjalan dengan baik bila semua modul dijadikan satu pada sebuah sistem. diagram blok pengujian tiap modul diperlihatkan pada Gambar 11 dan Gambar 12 untuk pengujian sensor proximity.

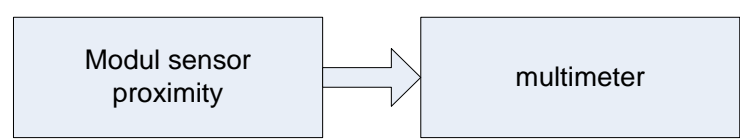

Gambar 11. Diagram Blok Pengujian Modul Sensor Proximity 


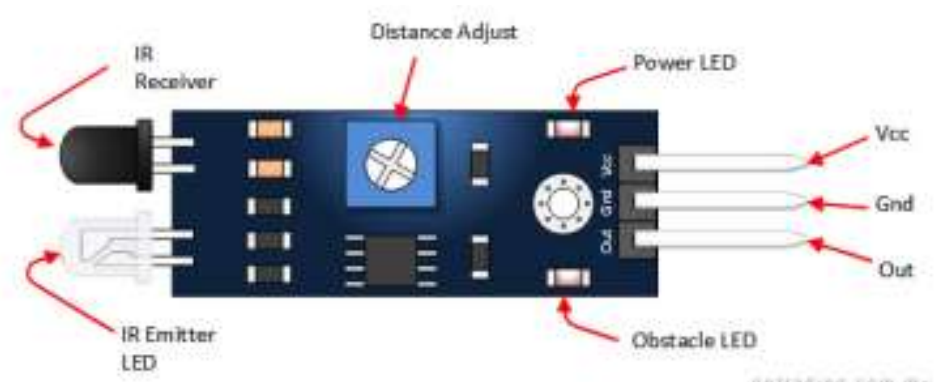

- Gambar 12. Pengujian Modul Sensor Proximity

Pengujian modul sensor proximity dengan tambahan modul power supply untuk men-suplly tegangan pada modul tersebut, lalu kemudian pin out pada modul tersebut dihubungkan dengan multimeter. Sensor akan dihalangi dengan benda, berapakah tegangan yang terukur pada multimeter.

Gambar 13 dan Gambar 14 memperlihatkan diagram blok pengujian modul relay.

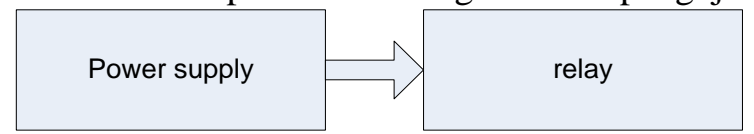

- Gambar 13. Diagram Blok Pengujian Modul Relay

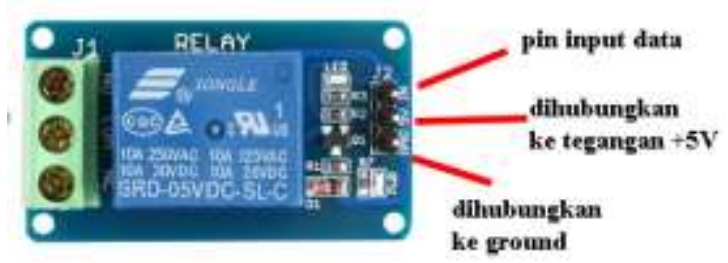

- Gambar 14. Pengujian Modul Relay

Pengujian modul relay dengan pin input data dihubungkan ke VCC $(+5 \mathrm{~V})$ atau ke ground. Jika dihubungkan ke VCC disebut dengan data "high", dan jika dihubungkan dengan ground disebut dengan data"low".

Pengujian relay dengan cara menggunakan power supply, selain power supply digunakan untuk tegangan supply pada modul. Relay bekerja atau tidak, dapat didengar pada perpindahan mekanik di dalam relay tersebut mengeluarkan bunyi, seperti memindahkan switch lampu.

Gambar 15 dan Gambar 16 memperlihatkan diagram blok pengujian transistor switching.

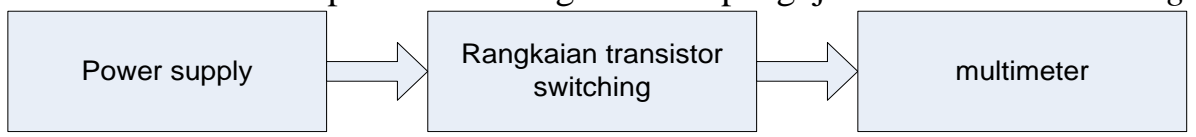

Gambar 15. Diagram Blok Pengujian Rangkaian Transistor Switching

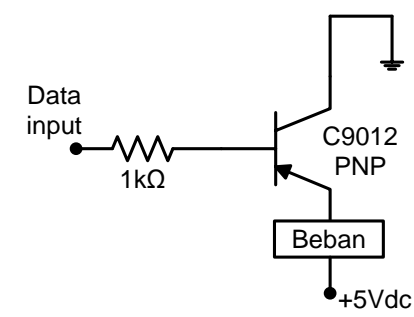

Gambar 16. Pengujian Rangkaian Transistor Switching

Pengujian dengan beban berupa lampu dengan tegangan $+5 \mathrm{Vdc}$, lalu pin data input diberikan tegangan $0 \mathrm{~V}$ (dengan dihubungkan ke ground) untuk data 0 , apakah lampu akan menyala. Pin data input dihubungkan ke tegangan $+5 \mathrm{Vdc}$ untuk data 1 , apakah lampu akan mati. 
Gambar 17 memperlihatkan diagram blok pengujian sistem pengendali air

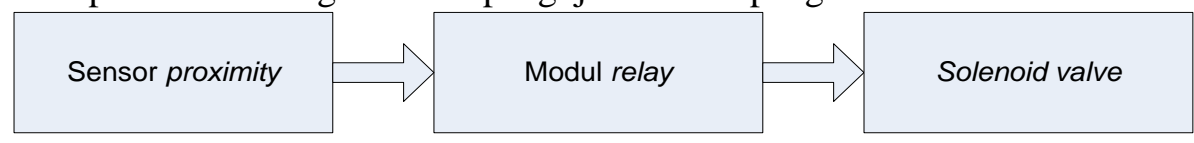

a Gambar 17. Diagram Blok Pengujian Sistem Pengendali Air

Pengujian sistem pengendali air dicoba dengan langsung dihubungkan dengan keran sebagai sumber air. Lalu solenoid valve diganti dengan pompa air untuk pengujian dengan tempat penampungan air, apakah air dapat keluar bila sensor mendeteksi tangan. Sistem sudah diaplikasikan untuk kedua cara tersebut. Gambar 18 memperlihatkan diagram blok pengujian sistem pengendali sabun cair

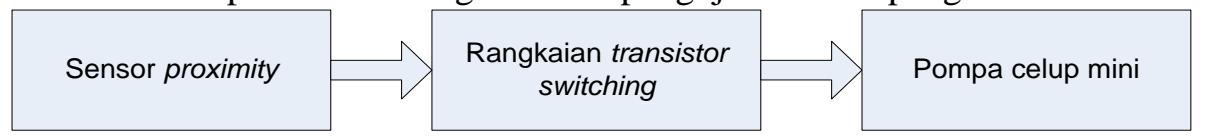

Gambar 18. Diagram blok Pengujian Sistem Pengendali Sabun Cair

Pengujian sistem dengan dicoba langsung pada tempat sabun cair yang dipasangi sistem ini, apakah sabun cair dapat keluar bila sensor mendeteksi tangan.

\section{HASIL DAN ANALISA SISTEM}

\section{Modul Sensor Proximity}

Cara pengujian dapat dilihat pada Gambar 19 dan hasil pengukuran pada Tabel 1.

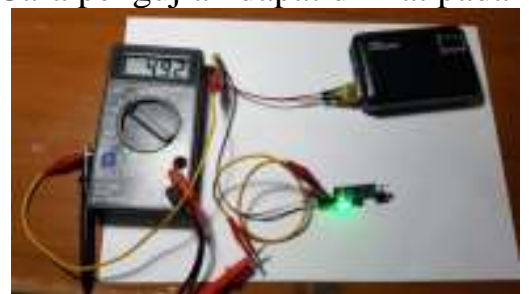

(a)

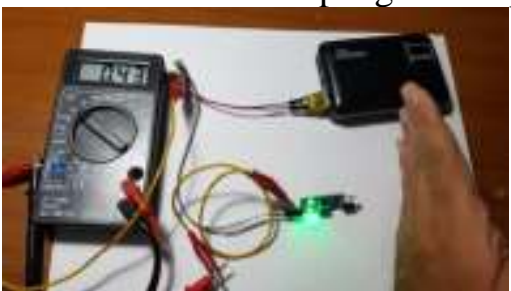

(b)

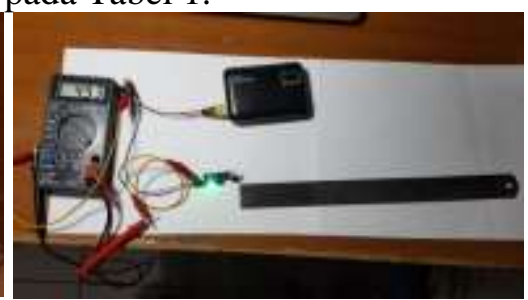

(c)

Gambar 19 Pengujian Modul Sensor Proximity Tanpa Halangan dan dengan Halangan Tangan

Gambar 19(a) menunjukkan pengujian sensor proximity tanpa halangan dan diperoleh nilai tegangan sebesar 4,92 Vdc pada voltmeter. Gambar 19(b) menunjukkan pengujian sensor proximity dengan halangan tangan dan diperoleh nilai tegangan sebesar 0,43 Vdc. Gambar 19(c) menunjukkan pengujian sensor proximity untuk mengukur jarak halangan tangan terhadap sensor.

Power supply dengan menggunakan power bank, jika 1 lampu yang menyala artinya modul tersebut stand-by. Lampu ke-2 yang menyala menandakan terdeteksinya sebuah objek. Hasil output terukur dengan multimeter dengan fungsi voltmeter.

Tabel 1. Hasil Pengujian Modul Sensor Proximity

\begin{tabular}{|c|c|c|}
\hline No & Jarak (cm) & Data Output \\
\hline \hline 1 & 0 & Low \\
\hline 2 & 1 & Low \\
\hline 3 & 2 & Low \\
\hline 4 & 5 & Low \\
\hline 5 & 10 & Low \\
\hline 6 & 20 & Low \\
\hline 7 & 30 & Low \\
\hline 8 & 31 & Low \\
\hline 9 & 32 & Low \\
\hline 10 & 33 & Low \\
\hline 11 & 34 & High \\
\hline 12 & 35 & High \\
\hline
\end{tabular}

Keterangan : $\quad H i g h=4,91-4,94$ volt Low $=0,41-0,43$ volt 


\section{Modul Relay}

Modul relay diuji tanpa dihubungkan dengan beban dan tanpa dihubungkan dengan modul sensor, hanya dengan bantuan power bank untuk tegangan supply. Langkah ini ditempuh agar mengetahui cara kerja dari modul ini. Cara pengujian seperti pada Gambar 20 dan hasil pada Tabel 2.

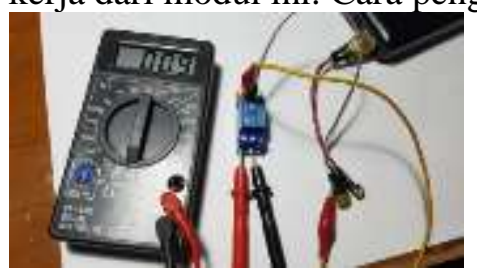

(a)

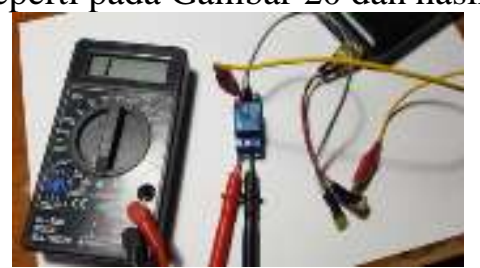

(b)

- Gambar 20. Pengujian Modul Relay dengan Data Input Low dan High

Power supply menggunakan power bank. LED merah pada modul relay menandakan modul stand-by, lampu hijau menandakan relay "on". Multimeter dengan fungsi Ohmmeter dipasang pada terminal COM-NO (pada gambar). Input data "low" dengan menghubungkan ke ground dari power supply, dan input data "high" dengan menghubungkan ke tegangan $5 \mathrm{Vdc}$ dari power supply.

Tabel 2. Hasil Pengujian Modul Relay

\begin{tabular}{|l|l|l|l|}
\hline No & Pin Data & \multicolumn{1}{|c|}{ Terminal NO } & Terminal NC \\
\hline \hline 1 & High & Open(Gambar 20 (a)) & Terhubung \\
\hline 2 & Low & Terhubung(Gambar 20(b)) & Open \\
\hline
\end{tabular}

Keterangan :

Open $=$ mempunyai nilai 1 pada layar multimeter, ini artinya nilai tahanan yang terukur tak hingga.

Terhubung $=$ mempunyai nilai $0,9 \mathrm{Ohm}$ pada layar multimeter, ini artinya nilai tahanannya kecil sekali (terhubung singkat) atau mendekati nilai 0 (nol).

\section{Modul Rangkaian Transistor Switching}

Cara pengujian seperti pada Gambar 21 dan Gambar 22, serta hasil pada Tabel 3.

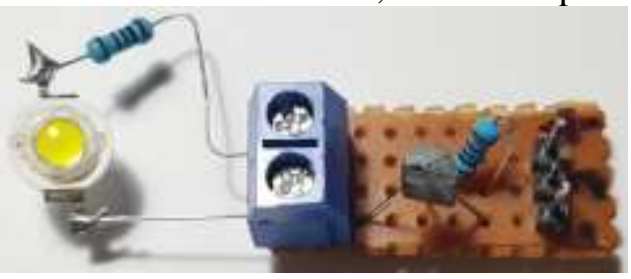

- Gambar 21. Rangkaian Transistor Switching dengan Beban Lampu DC
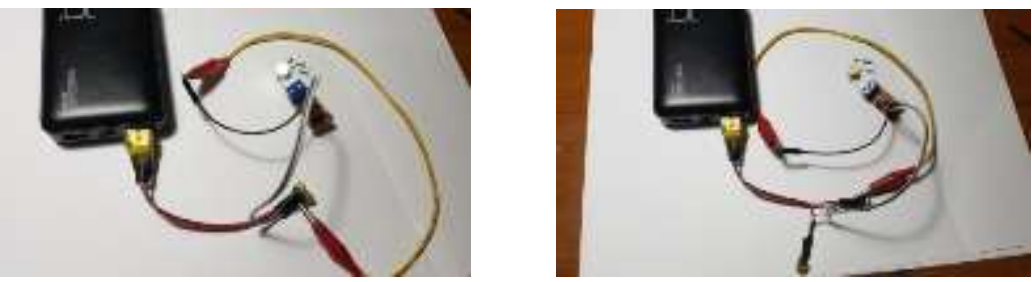

- Gambar 22. Pengujian Rangkaian Transistor Switching dengan Data "Low" dan "High"

Rangkaian transistor dengan karakteristik aktif "low", jika pin data diberi data low atau dihubungkan ke ground maka transistor akan "on" ditandai oleh lampu yang menyala, sedangkan jika pin data diberi data high atau dihubungkan ke tegangan +5 Vdc maka transistor akan "off" ditandai oleh lampu yang mati.

Tabel 3. Hasil Pengujian Rangkaian Transistor Switching

\begin{tabular}{|l|l|l|}
\hline No & Pin Data & Kondisi Lampu \\
\hline \hline 1 & High & Mati \\
\hline
\end{tabular}




\begin{tabular}{|l|l|l|}
\hline 2 & Low & Menyala \\
\hline
\end{tabular}

\section{Sistem Pengendali Air dan Sistem Pengendali Sabun Cair}

Sistem ini sudah diterapkan dan di uji langsung pada tempat penampungan air dan botol sabun cair. Sumber air pada penampungan air maka digunakan pompa air dengan daya AC, pompa air ini diganti dengan solenoid valve bila sumber air dari saluran keran air. Sistem dapat digunakan tanpa mengubah apapun, hanya mengganti jenis beban saja antara solenoid valve atau pompa air. Gambaran sistem pengendali air dan pengendali sabun cair dapat dilihat pada Gambar 23.

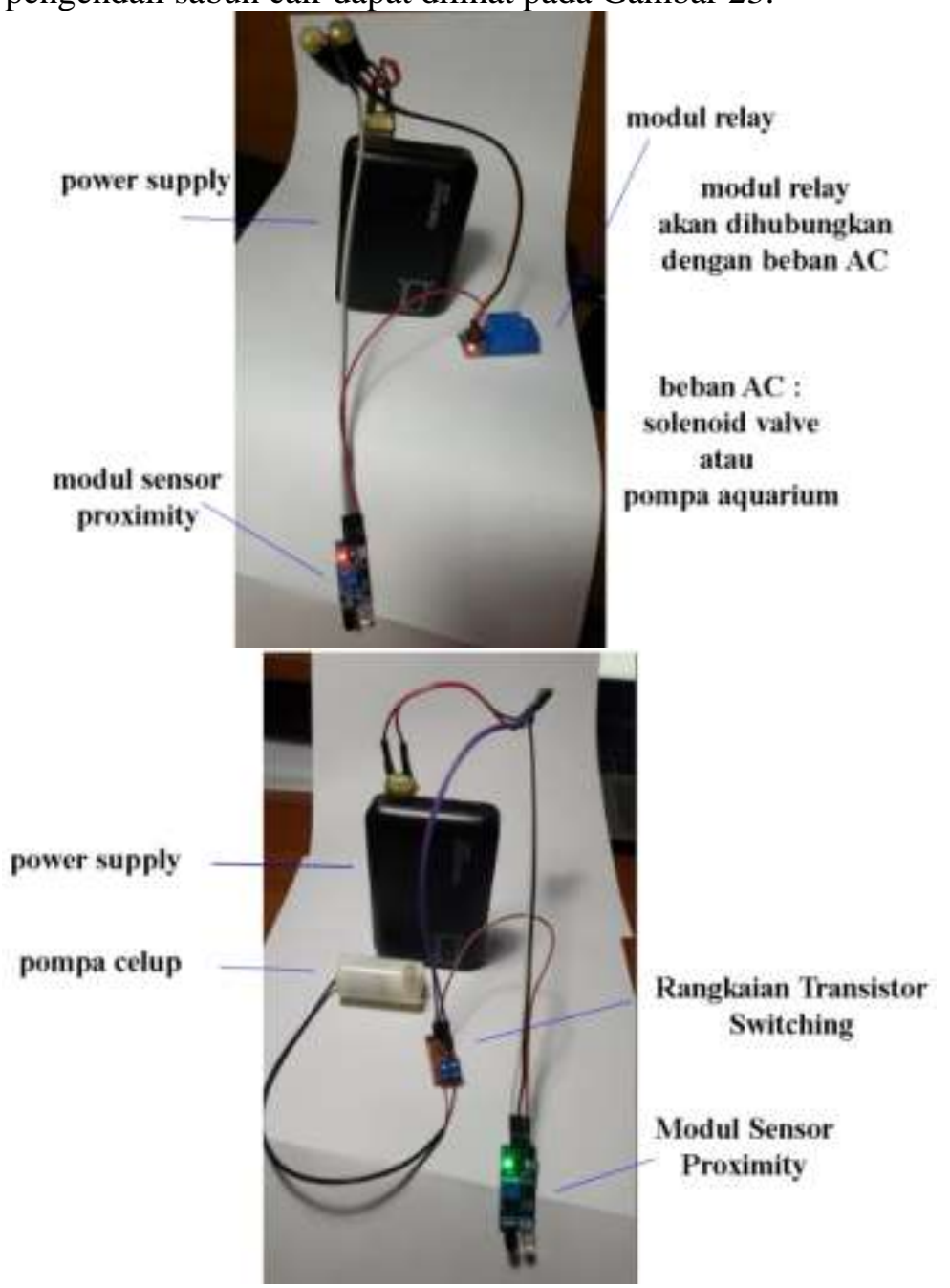

Gambar 23. Pengujian Sistem Pengendali Air dan Pengendali Sabun Cair

Sistem diuji dengan mendekatkan tangan pada sensor, dan modul relay akan "on" atau rangkaian transistor switching akan "on" disertai pompa DC yang menyala. Pengujian beberapa kali, dan hasilnya semua berhasil.

Link hasil pengujian dapat dilihat pada :

- https://www.youtube.com/watch?v=OZ-x2m0g6KE\&t=26s $\rightarrow$ sistem pengendali air

- https://www.youtube.com/watch?v=wtVRdwVx1n4 $\rightarrow$ sistem pengendali sabun cair

- https://www.youtube.com/watch?v=D6DGmWfPobc $\rightarrow$ cara pasang sistem pengendali air

- https://www.youtube.com/watch?v=a4ZxuGqeKrk\&t=2s $\rightarrow$ cara pasang sistem pengendali sabun cair

- $\quad$ https://www.youtube.com/watch?v=gi5XiWMZuNU\&t=69s $\rightarrow$ pengujian keseluruhan sistem

\section{KESIMPULAN DAN SARAN}

Kesimpulan dari penelitian ini bahwa semua sistem bekerja dengan baik dan penggunaan solenoid valve atau pompa air disesuaikan dengan aplikasi di lapangan. Aplikasi di lapangan yang di maksud adalah penggunaan sumber air, menggunakan penampungan air atau langsung dari saluran keran air. 
Saran dari penelitian ini dengan dicoba beberapa jenis sensor selain sensor infra merah proximity.

\section{DAFTAR PUSTAKA}

[1] H. Sukri. Perancangan Mesin Cuci Tangan Otomatis dan Higienis Berbasis Kamera. Jurnal Rekayasa. Vol.12. No.2. 163-167. 2019

[2] H. Rizki dan Wildian. Rancang Bangun Sistem Wastafel Otomatis Berbasis Mikrokontroler ATmega8535 dengan Menggunakan Sensor Fotodioda. Jurnal Fisika Unand. Vol.2.No.2. 106-112. 2015.

[3] H. Hendri. Pembersih Tangan Otomatis Dilengkapi Air, Sabun, Handdryer dan LCD Menggunakan Sensor Infrared Berbasis Arduino. Jurnal Teknologi. Vol.8.No.1. 1-14. 2018.

[4] D. Susilo, M.Julius dan O. Setyawati. Rancang Bangun Dan Implementasi Sistem Pencuci Tangan (Hand Washer) Dan Pengering Tangan (Hand Dryer) Otomatis Berbasis Mikrokontroler Atmega 8535. Jurnal Mahasiswa TEUB. Vol.3.No.4. 2015.

[5] T. Rahman, D.W.Nugraha dan Y.Anshori. Pengendalian Sistem Pencuci Dan Pengering Tangan Otomatis Menggunakan Sensor Passive Infra Red (PIR). Jurnal Mektrik. Vol.2.No.1. 2015. 